Gut, 1989, 30, 866-872

\title{
Reversible gall bladder dysfunction in severe pancreatic insufficiency
}

\author{
A A M MASClEE, J B M J JANSEN, F H M CORSTENS, \\ AND C B H W LAMERS \\ From the Department of Medicine, Division of Gastroenterology, University Hospital Nijmegen, Nijmegen, \\ Department of Gastroenterology, University Hospital Leiden, Leiden, and Department of Nuclear Medicine, St \\ Radboud Hospital, University of Nijmegen, Nijmegen, The Netherlands
}

SUMMARY The present study was undertaken to examine the intestinal phase of cholecystokinin (CCK) secretion and gall bladder contraction in patients with severe pancreatic insufficiency. Plasma CCK concentrations, measured by radioimmunoassay, and gall bladder contraction by cholescintigraphy were studied in response to intraduodenal fat with and without addition of pancreatic enzymes. Fasting plasma CCK concentrations were in the same range in six patients with pancreatic insufficiency with $(2 \cdot 6(0 \cdot 2) \mathrm{pmol} / \mathrm{l})$ and without $(2 \cdot 6(0 \cdot 3) \mathrm{pmol} / \mathrm{l})$ addition of pancreatic enzymes and in six healthy subjects $(2.0(0 \cdot 4) \mathrm{pmol} / \mathrm{l})$. The integrated plasma CCK secretion in response to intraduodenal fat was significantly $(\mathbf{p}<0 \cdot 005)$ reduced in the patients without addition of enzymes (46 (13) pmol/1.90 min) compared with healthy subjects (199 (22) pmol/1.90 min), but increased significantly $(\mathbf{p}<0.01)$ by the addition of pancreatic enzymes $(174(25) \mathrm{pmol} / 1.90 \mathrm{~min})$ to values not significantly different from healthy subjects. Similarly, gall bladder emptying in response to intraduodenal fat was significantly $(\mathbf{p}<0 \cdot 01)$ reduced in patients with pancreatic insufficiency without addition of enzymes (at 90 min: 35 (11)\%) compared with healthy subjects (at 90 min: 66 (7)\%) but significantly $(\mathbf{p}<0 \cdot 01)$ increased by addition of pancreatic enzymes (at $90 \mathrm{~min}: 70(8) \%)$ to values not significantly different from healthy subjects. These results indicate that patients with severe pancreatic insufficiency have impaired gall bladder emptying after intraduodenal fat, which can be normalised by the addition of pancreatic enzymes. This impaired gall bladder emptying appears to be the result of a reduced plasma CCK response. Thus, intra-intestinal pancreatic enzymes play an important role in the intestinal phase of CCK secretion and gall bladder emptying.

The role of cholecystokinin (CCK) in the intestinal phase of pancreatic enzyme secretion and gall bladder contraction has been well established. ${ }^{12}$ Abnormalities of CCK have been described in patients with pancreatic insufficiency. ${ }^{3-14}$ Raised fasting and postprandial plasma CCK concentrations in patients with various degrees of chronic pancreatitis have been reported by some authors, ${ }^{3-8}$ suggesting that increased plasma CCK concentrations result from impaired inhibition of CCK secretion by pancreatic enzymes. In subsequent studies, however,

Address for correspondence: Ad A M Masclee, MD, Department of Medicine. Division of Gastroenterology, St Radboud Hospital, University of Nijmegen. PO Box 9101, 6500 HB Nijmegen, The Netherlands.

Accepted for publication 7 November 1988. using the same radioimmunoassay system the findings could not always be confirmed. ${ }^{910}$ In fact, in recent studies using specific radioimmunoassays for CCK fasting and postprandial plasma CCK concentrations in patients with chronic pancreatitis and pancreatic insufficiency were found to be in the normal range ${ }^{y-11}$ or significantly reduced. ${ }^{12-14}$ Analysing the studies reporting normal postprandial plasma CCK secretion in more detail, it became apparent that in several of the studies on patients with severe pancreatic insufficiency, a reduced CCK secretion was found, although this reduction failed to reach statistical significance. ${ }^{-11}$ In fact, these studies showed a significant delay of the plasma CCK peak after the meal. ${ }^{-11}$ 
The latter finding of a diminished postprandial CCK secretion is in accordance with previous studies in dog and man indicating that digestion of nutrients is required for stimulation of CCK secretion as monitored by in vivo pancreatic enzyme secretion. ${ }^{15} 16$ The present study was undertaken to determine whether a decreased postprandial plasma CCK secretion in patients with pancreatic insufficiency was reflected in a diminished gall bladder contraction. A second aim of the study was to investigate whether by supplying sufficient amounts of intra-intestinal pancreatic enzymes, postprandial plasma CCK secretion and gall bladder contraction could be improved in patients with pancreatic insufficiency. Therefore we have examined the intestinal phase of CCK secretion and gall bladder emptying in patients with severe pancreatic insufficiency by administration of the stimulus into the duodenum without and with addition of pancreatic enzymes.

\section{Methods}

\section{SUBJECTS}

Six male patients (mean age 41 years, range 32-52) with severe pancreatic insufficiency were studied. Pancreatic insufficiency was caused by alcoholic pancreatitis in three patients, by chronic pancreatitis of unknown origin in two patients and one patient had the Shwachman syndrome. The faecal fat excretion ranged from $12-37 \mathrm{~g} / 24 \mathrm{~h}$ (normal $<7.5 \mathrm{~g} / 24 \mathrm{~h}$ ). Pancreatic enzyme supplements were discontinued at least three days before the examination. None of the patients had insulin dependent diabetes mellitus or signs of chronic liver disease and routine liver function tests were normal in all of them. In addition, six male healthy control subjects (mean age 38 years, range 25-55) without known gastrointestinal or metabolic diseases were studied. Gall stone disease in the patients and in the healthy subjects was excluded by ultrasonography. The protocol has been approved by the local ethical committee and informed consent was obtained from each person.

Gall bladder emptying was measured by qantitative cholescintigraphy. ${ }^{17}$ After an overnight fast each subject was given an intravenous bolus injection of technetium 99M 2,6-dimethylphenylcarbomoylmethyl iminodiacetic acid $\left({ }^{99 m} \mathrm{Tc}\right.$ HIDA). The administered dose was $3 \mathrm{mCi}(111 \mathrm{MBq})$. During the gall bladder filling period a small tube was inserted by mouth and the tip was positioned, under fluoroscopic control, in the upper or second part of the duodenum. When the ${ }^{99 \mathrm{~m}} \mathrm{Tc}$ HIDA activity in the gall bladder had reached its maximum, usually about 60 minutes after the injection, the subject was positioned supine beneath a large-field-of-view gamma scintillation camera interfaced to a microcomputer system. At the start of the study the stimulus was administered through the tube into the duodenum within two minutes. Serial images were obtained for 90 minutes in frames of one minute. At a later instance the images were replayed and the area of interest - that is, the gall bladder - was outlined according to the distribution of activity using a light pen. A time activity curve of the 90 one minute periods was obtained, corrected for radioactive decay and plotted. The number of counts within the gall bladder region at the start of the study was defined as $100 \%$ and served as the reference point for determining the gall bladder ejection fraction.

At minus five and zero minutes before and every five minutes for 30 minutes and every 10 minutes from 30 through 90 minutes a blood sample was drawn for measurement of CCK. Cholecystokinin was measured in plasma by a sensitive and specific radioimmunoassay. ${ }^{19}$ The CCK antibody T204,

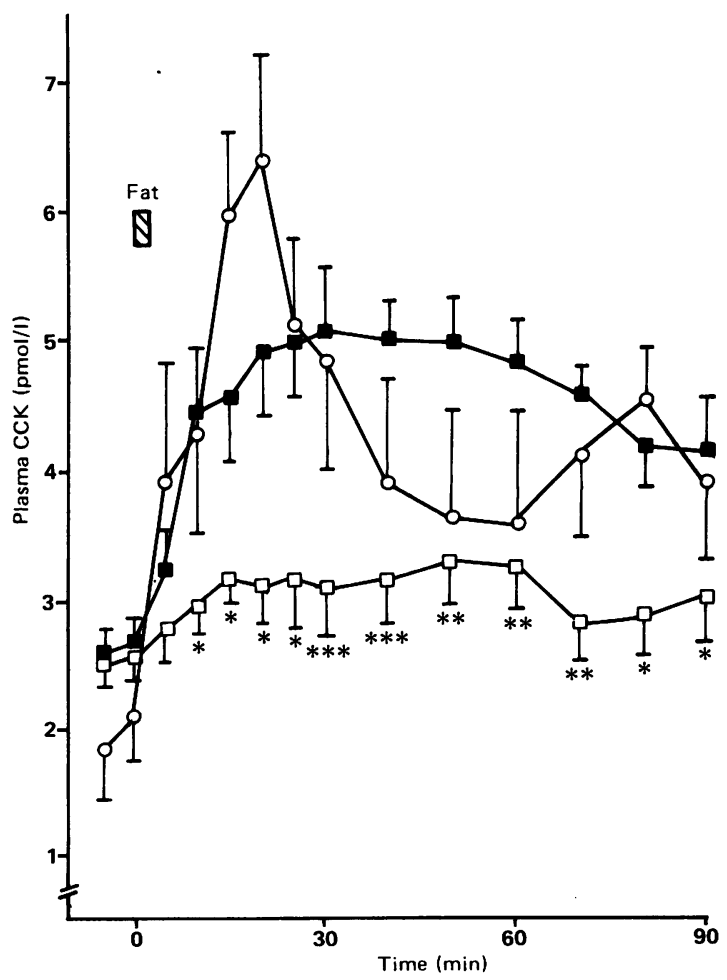

Fig. 1 Plasma CCK concentrations in response to intraduodenal fat in six patients with pancreatic insufficiency without addition of pancreatic enzymes (open squares) and with addition of pancreatic enzymes (closed squares) and in six healthy controls (open circles). Asterisks denote significant differences in the patients without enzyme supplementation compared with the results after addition of the enzymes $\left({ }^{*} p<0.05,{ }^{* *} p<0.01,{ }^{* * *} p<0.005\right)$. 
raised in a rabbit after the fourth immunisation with albumin coupled CCK, was used in a final dilution of $1: 80,000$. The antibody bound to all carboxy-terminal CCK peptides containing the sulphated tyrosyl region. The antibody showed very low cross reactivity with sulphated gastrins (about $2 \%$ ), but did not show any binding to unsulphated gastrins or structurally unrelated regulatory peptides. Ninety nine per cent pure CCK-33 coupled to 125 I hydroxyphenyl-propionic acid succinimide ester (Bolton-Hunter reagent) was used as label and $99 \%$ pure CCK was used as standard preparation. The detection limit of the assay was between 0.6 and $1 \mathrm{pmol} / \mathrm{l}$ plasma. The intra-assay variation ranged from 4.6 to $11.5 \%$ and the interassay variation from $11 \cdot 3$ to $26 \cdot 1 \%$. $^{18}$

At the start of the study $60 \mathrm{ml}$ of corn oil with and without addition of pancreatic enzymes of porcine origine $(225 \mathrm{kU}$ lipase and $190 \mathrm{kU}$ protease, Pancreas-Granulaat, Organon, The Netherlands) was administered through the tube into the duodenum. This dose of corn oil has proved to be a powerful stimulus for CCK release and gall bladder contraction. ${ }^{20}$ The patients with pancreatic insufficiency were studied twice, on separate occasions with an interval of 14 days, in random order with and without addition of pancreatic enzymes to the corn oil. In two patients the effects of addition of the same amount of pancreatic enzymes, boiled for five minutes, to the corn oil, was also studied; no trypsin or lipase activity was demonstrable after boiling the enzyme extract. In two healthy subjects the effect of administration of the same amount of pancreatic enzymes without corn oil was studied in order to investigate whether pancreatic enzymes alone are able to release CCK.

\section{STATISTICAL ANALYSIS}

Results were expressed as mean (SEM). The integrated CCK secretion after intraduodenal fat
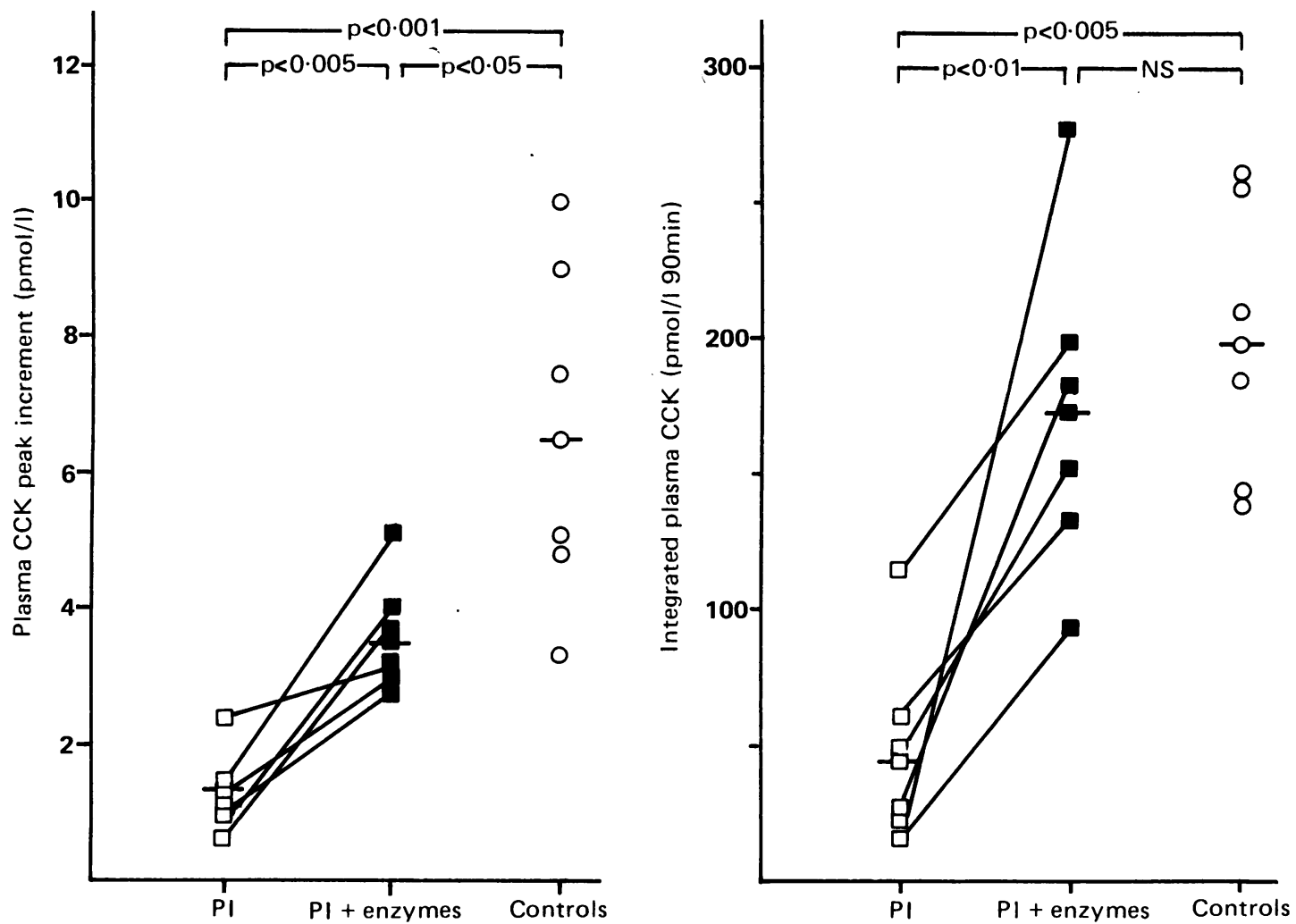

Fig. 2 Left panel: individual data and mean of peak increments in plasma CCK after intraduodenal fat in six patients with pancreatic insufficiency (PI) without addition of pancreatic enzymes (open squares) and with addition of pancreatic enzymes (closed squares) and in six healthy controls (open circles). Right panel: individual data and mean of integrated plasma CCK responses to intraduodenal fat in six patients with pancreatic insufficiency (PI) without (open squares) and with addition of pancreatic enzymes (closed squares) and in six healthy controls (open circles). 
with and without addition of pancreatic enzymes was determined by calculating the area under the plasma concentration time curve after subtraction of the basal value. Integrated gall bladder emptying was determined by calculating the area under the gall bladder emptying time curve. Statistical analysis of the results was carried out by Student's $t$ test for paired and unpaired data.

\section{Results}

\section{ENDOGENOUS CCK SECRETION}

Fasting plasma CCK concentrations in the six patients with pancreatic insufficiency without $(2 \cdot 6$ $(0.3) \mathrm{pmol} / \mathrm{l})$ and with $(2.6(0.2) \mathrm{pmol} / \mathrm{l})$ addition of pancreatic enzymes and in the six healthy control subjects $(2.0(0.4) \mathrm{pmol} / \mathrm{l})$ were not significantly different (Fig. 1). Intraduodenal administration of fat resulted in a significant $(p<0.05)$ increase in plasma CCK over basal in the patients without addition of enzymes only from 40 through 60 minutes while in the same patients with enzymes added to the fat meal and in the healthy subjects plasma CCK significantly $(p<0.001-p<0.05)$ increased from 10 minutes continuing for the entire experiment. In the patients with pancreatic insufficiency plasma CCK concentrations in response to fat with addition of enzymes were significantly $(p<0.005-p<0.05)$ raised over those in response to fat without enzymes starting from 10 minutes and continuing during the entire study period. No significant differences in plasma CCK between the patients with addition of enzymes and the healthy subjects were found while in the patients without addition of enzymes plasma CCK concentrations were significantly $(\mathrm{p}<0.001-\mathrm{p}<0 \cdot 05)$ reduced at 15,20, and 25 minutes compared with the healthy subjects. Addition of enzymes to the fat meal significantly $(\mathrm{p}<0.005)$ increased peak increments in plasma CCK from $1 \cdot 2(0 \cdot 2) \mathrm{pmol} / 1$ to $3 \cdot 6(0 \cdot 3) \mathrm{pmol} / \mathrm{l}$ in the patients with pancreatic insufficiency (Fig. 2,

Table Effect of addition of boiled pancreatic enzymes on plasma CCK and gall bladder responses to intraduodenal fat in two patients with pancreatic insufficiency

\begin{tabular}{llll}
\hline & $\begin{array}{l}\text { No } \\
\text { enzymes enzymes enzymes }\end{array}$ \\
\hline $\begin{array}{l}\text { Integrated plasma CCK } \\
\text { (pmol/1.90 min) } \\
\quad \text { Patient 1 }\end{array}$ & & & \\
$\quad$ Patient 2 & 23 & 45 & $188 \mathrm{pmol} / 1.90 \mathrm{~min}$ \\
Gall bladder emptying (\% at & 16 & 10 & $94 \mathrm{pmol} / 1.90 \mathrm{~min}$ \\
$\quad 90$ min) & & & \\
$\quad$ Patient 1 & 63 & 55 & $92 \%$ \\
$\quad$ Patient 2 & 2 & 9 & $60 \%$ \\
\hline
\end{tabular}
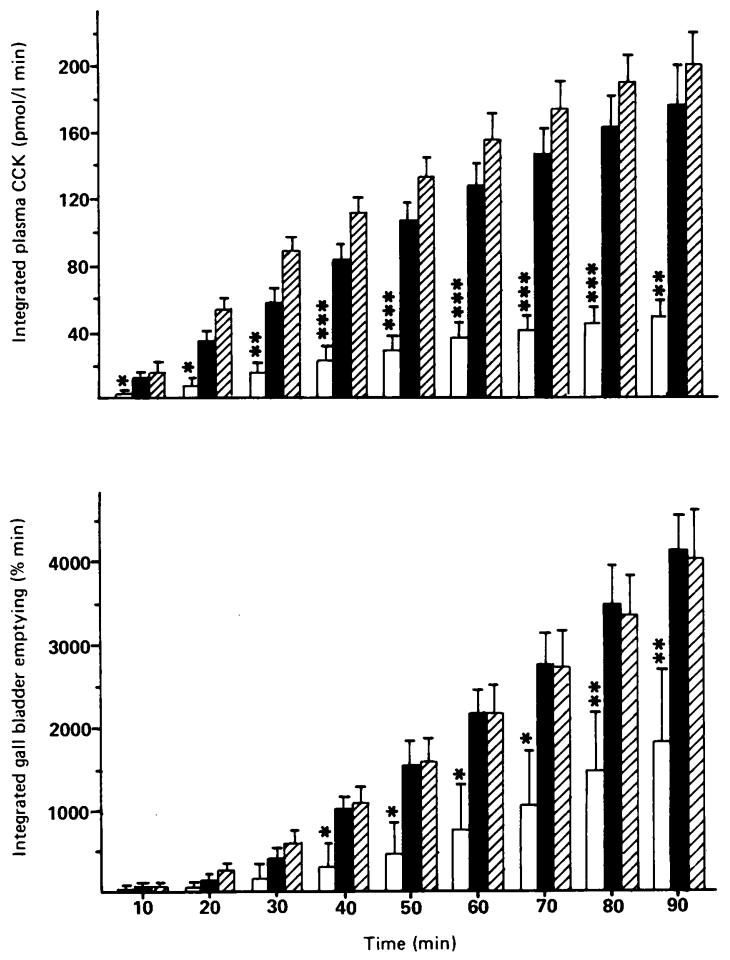

Fig. 3 Integrated plasma CCK secretion (upper panel) and integrated gall bladder emptying (lower panel) in response to intraduodenal fat in six patients with pancreatic insufficiency without addition of pancreatic enzymes (open bars) and with addition of pancreatic enzymes (solid bars) and in six healthy subjects (striped bars). Asterisks denote significant

differences between patients without addition of enzymes and healthy subjects and in the patients without and with addition of enzymes $\left({ }^{*} p<0.05,{ }^{* *} p<0.01,{ }^{* * *} p<0.005\right)$.

left panel). Peak increments in plasma CCK after addition of enzymes, however, remained significantly $(p<0.05)$ reduced when compared with healthy subjects. The integrated plasma CCK response to intraduodenal fat was significantly $(\mathrm{p}<0.005-$ $p<0.05)$ lower from 10 minutes through the entire study in the patients without addition of enzymes when compared with addition of enzymes or to the healthy subjects (Fig. 3, upper panel). The integrated plasma CCK secretion calculated for the entire 90 min study period was $46(13) \mathrm{pmol} / 1.90 \mathrm{~min}$ in the patients without enzymes, 174 (25) pmol/1.90 $\mathrm{min}$ in the patients with enzymes and 199 (22) pmol/1.90 min in the healthy subjects (Fig. 2, right panel).

GA LL BLA D DER EMPTYING

The significantly $(\mathrm{p}<0 \cdot 01)$ delayed rise in plasma CCK in the patients without enzymes was accom- 


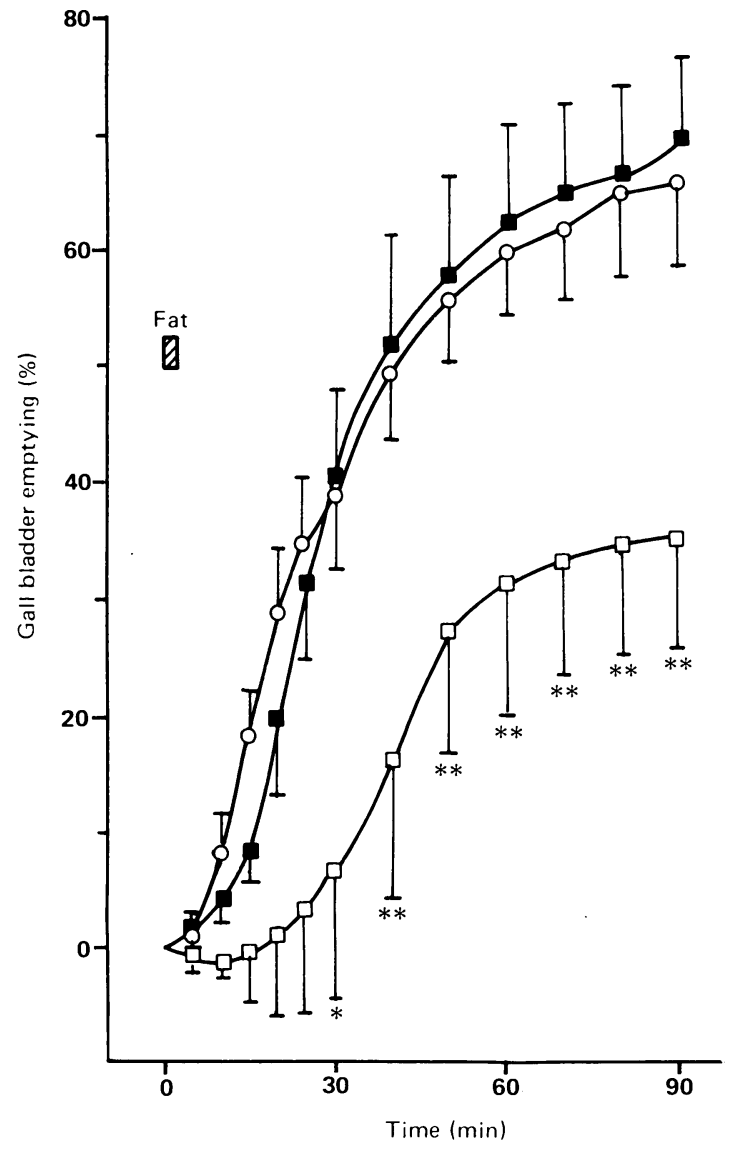

Fig. 4 Gall bladder emptying in response to intraduodenal fat in six patients with pancreatic insufficiency without (open squares) and with addition of pancreatic enzymes (closed squares) and in six healthy subjects (open circles). The asterisks denote significant differences in gall bladder emptying in the patients when compared with the healthy control subjects $\left({ }^{*} p<0 \cdot 05,{ }^{* *} p<0 \cdot 01\right)$.

panied by a significantly $(\mathrm{p}<0 \cdot 01)$ later onset of gall bladder emptying (32 (4) min), when compared with the study with addition of enzymes (10 (2) min) and to the healthy subjects ( 9 (2) min, Fig. 4). Gall bladder emptying was significantly $(p<0 \cdot 01-p<0 \cdot 05)$ reduced from 30 minutes through the entire study in the patients without enzymes compared with healthy subjects. By addition of pancreatic enzymes gall bladder emptying in the patients significantly $(p<0.01-p<0.05)$ increased to values not significantly different from healthy subjects. After 90 minutes gall bladder emptying was $35(11) \%$ in the patients without enzymes, $70(8) \%$ in the patients with enzymes and $66(7) \%$ in the healthy subjects (Fig. 5).
Integrated gall bladder emptying was significantly $(\mathrm{p}<0.01-\mathrm{p}<0.05)$ reduced in the patients without enzymes compared with addition of enzymes or to the healthy subjects beginning at 40 minutes and continuing for the entire study period (Fig. 3, lower panel).

Addition of boiled pancreatic enzymes to corn oil in two patients with pancreatic insufficiency did not influence CCK release and gall bladder emptying (Table). The plasma CCK concentrations found in two healthy subjects during the 90 minute study period after intraduodenal administration of pancreatic enzymes alone $(2.4(0.2) \mathrm{pmol} / \mathrm{l})$ were not significantly different from fasting plasma CCK concentrations $(2 \cdot 0(0 \cdot 4) \mathrm{pmol} / \mathrm{l})$.

\section{Discussion}

In the present study it was shown that fasting plasma CCK concentrations in patients with severe pancreatic insufficiency were in the same range as in healthy subjects. The endogenous CCK secretion and gall bladder emptying in response to intraduodenal fat were, however, significantly reduced in patients with severe pancreatic insufficiency. It was further shown that the endogenous CCK secretion and gall bladder emptying could be normalised by the addition of pancreatic enzymes.

The present finding of normal basal plasma CCK concentrations in patients with pancreatic insufficiency is in agreement with the findings of several other reports. ${ }^{9-11} 11^{1+1+}$ In previous studies, however, increased as well as decreased fasting and postprandial plasma CCK concentrations were found in patients with chronic pancreatitis with or without impairment of pancreatic function. ${ }^{3-\infty}{ }^{12-1+}$ The reason for these contrasting results is not apparent but may be related to the characteristics of the CCK assays or to differences in the severity of exocrine insufficiency in the patients studied.

Theoretically, several mechanisms may be responsible for the reversible reduction in $\mathrm{CCK}$ secretion and gall bladder emptying in patients with pancreatic insufficiency. First, a reduced postprandial plasma CCK secretion may be caused by impaired gastric emptying of the meal. The effect of gastric emptying, however, was precluded by administration of the stimulus directly into the duodenum. Second, a reduced functional capacity of the upper small intestine to release CCK could have caused a decreased postprandial plasma CCK secretion in patients with pancreatic insufficiency. This possibility is highly unlikely because the endogenous CCK secretion was normalised by the addition of pancreatic enzymes to the fat meal. A more likely explanation for the reduced plasma CCK response to 


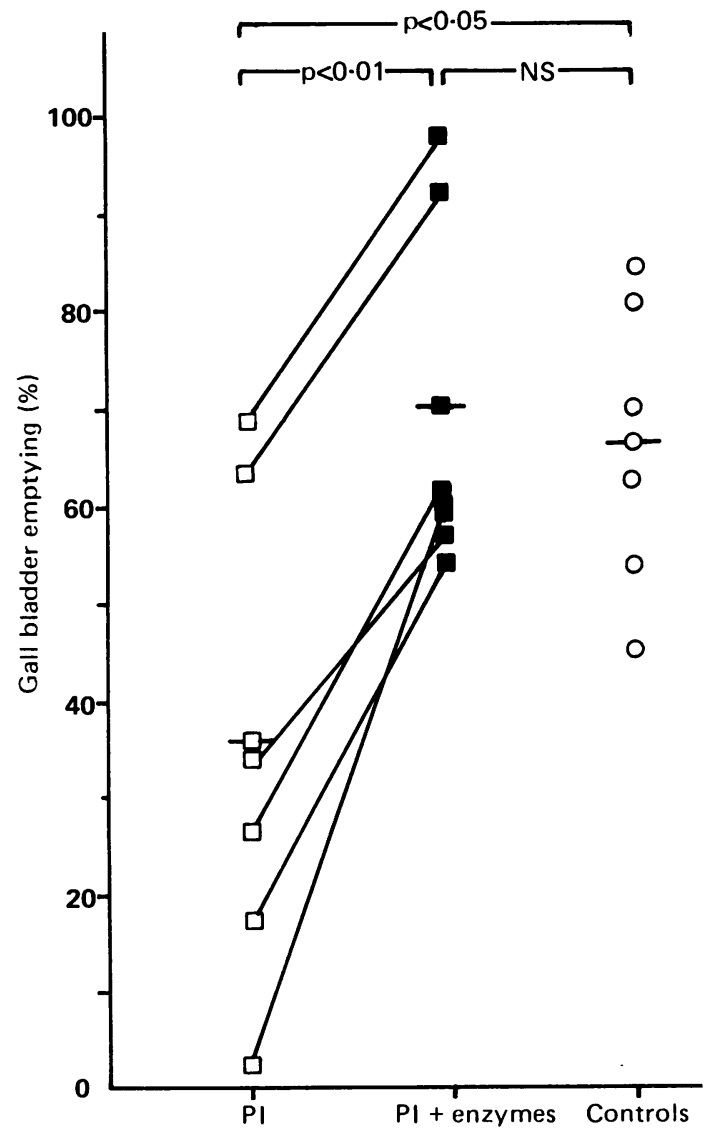

Fig. 5 Individual data and mean of gall bladder emptying 90 minutes after intraduodenal fat in six patients with pancreatic insufficiency (PI) without (open squares) and with addition of pancreatic enzymes (closed squares) and in six healthy subjects (open circles).

intraduodenal fat in these patients is related to the finding that plasma CCK release is dependent on the digestion of proteins and fat which is affected in patients with pancreatic insufficiency as a result of a decreased pancreatic enzyme secretion. In dog and man it has been shown that luminal digestion of nutrients is required for stimulation of plasma CCK secretion measured by either radioimmunoassay or in vivo pancreatic secretion. ${ }^{13-16}$ In other words, stimulation of exocrine pancreatic secretion leading to adequate intra-intestinal pancreatic enzyme activity is needed for digestion of proteins and fat to oligopeptides, amino acids and fatty acids in order to release CCK. By increasing the intraintestinal pancreatic enzyme activity through addition of pancreatic enzymes, the endogenous CCK secretion and gall bladder emptying could be normalised in patients with pancreatic insufficiency. The shape of the CCK response curves to fat was slightly, although not significantly, different showing an early peak in the healthy control subjects and a more continuous, somewhat blunted response in the patients with pancreatic insufficiency after addition of the pancreatic enzymes. The reason for this difference is not apparent but may be related to a readier digestion of triglycerides because of more effective activation of a duodenopancreatic reflex mechanism leading to a more pronounced early enzyme output into the duodenum of healthy subjects. ${ }^{21}$ No study on gall bladder function in patients with impaired pancreatic function has been reported previously. In one study gall bladder contraction has been investigated in patients with chronic pancreatitis. ${ }^{22}$ In that study the gall bladder contraction in response to exogenous CCK was found to be impaired in patients with chronic pancreatitis, suggesting a decreased sensitivity of the gall bladder to CCK. The finding from the present study that impaired gall bladder emptying in patients with pancreatic insufficiency is the result of a reduced endogenous CCK secretion seems to be in contrast with the reduced gall bladder sensitivity to CCK found in the previously mentioned study. These contrasting results may, however, be due to several factors. First, plasma CCK concentrations were not monitored in the study with exogenous CCK and therefore it is not known whether plasma CCK concentrations were in the physiological postprandial range. Second, the different results between the meal and exogenous CCK stimulated gall bladder emptying may be related to the type of patients studied. While we examined patients with severely impaired pancreatic function, in the study with exogenous CCK, patients with chronic pancreatitis were investigated. Whether pancreatic function was impaired in these patients was not reported. The present study is the first to report, in accordance to a significantly decreased CCK secretion, a significantly impaired gall bladder contraction in response to a fat meal in patients with pancreatic insufficiency. It is possible that the maldigestion and malabsorption of nutrients in patients with pancreatic insufficiency is aggravated by a reduced postprandial gall bladder contraction.

The present study also revealed that endogenous CCK secretion and gall bladder contraction in patients with severe pancreatic insufficiency were restored by addition of pancreatic enzymes to the corn oil. Theoretically it is possible that factors other than pancreatic enzymes present in the pancreatic enzyme preparation stimulate CCK secretion. Therefore, in two patients the addition of boiled pancreatic enzymes to the corn oil was studied. After boiling the pancreatic enzyme extract no lipase or trypsin activity was demonstrable. Addition of boiled 
pancreatic enzymes to the corn oil did not influence CCK secretion and gall bladder emptying. Although this is an argument strongly in favour of the beneficial effect of pancreatic enzymes on CCK release in patients with pancreatic insufficiency, the effect of other heat labile factors cannot be excluded.

It is not known whether CCK is released after intraduodenal administration of pancreatic enzymes alone. Therefore, in two healthy subjects plasma CCK concentrations were determined after intraduodenal administration of pancreatic enzymes without corn oil. After administration of pancreatic enzymes alone no effect on CCK secretion could be shown.

From the present study it can be concluded that (1) patients with severe pancreatic insufficiency have impaired gall bladder emptying after corn oil, (2) that gall bladder emptying can be normalised by the addition of pancreatic enzymes, (3) that the impaired gall bladder emptying seems to be the result of a reduced plasma CCK secretion, and (4) that intraintestinal pancreatic enzymes play an important role in the intestinal phase of CCK secretion and gall bladder emptying.

\section{References}

1 Beglinger C, Fried M, Whitehouse I, Jansen JB, Lamers $\mathrm{CB}$, Gyr K. Pancreatic enzyme response to a liquid meal and to hormonal stimulation. Correlation with plasma secretin and cholecystokinin levels. J Clin Invest 1985; 75: $1471-6$.

2 Wiener I, Inoue K, Fagan CJ, Lilja P, Watson LC, Thompson JC. Release of cholecystokinin in man. Correlation of blood levels with gallbladder contraction. Ann Surg 1981; 194: 321-7.

3 Harvey RF, Dowsett L, Hartog M, Read AE. A radioimmunoassay for cholecystokinin-pancreozymin. Lancet 1973; ii: 826-8.

4 Harvey RF, Rey JF, Howard JM, et al. Bioassay and radioimmunoassay of serum cholecystokinin in paticnts with pancreatic disease. Rend Gastroenterol 1977; 9: $15-6$.

5 Elderle A, Vantini J, Harvey RF, et al. Fasting serum cholecystokinin levels in chronic relapsing pancreatitis. Ir J Med Sci 1977; 146: 30.

6 Slaff JI, Wolfe MM, Toskes PP. Elevated fasting cholecystokinin levels in pancreatic exocrine impairment: evidence to support feedback regulation. $J$ Lab Clin Med 1985; 105: 282-5.

7 Schafmayer A, Becker HD, Werner M, Fölsch UR,
Creutzfeldt W. Plasma cholecystokinin levels in patients with chronic pancreatitis. Digestion 1985; 32: 136-9.

8 Becker HD, Werner M, Schafmayer A. Release of radioimmunologic cholecystokinin in human subjects. Am J Surg 1984; 147: 124-8.

9 Bozkurt T, Alder G, Koop I, Koop H, Türmer W, Arnold R. Plasma CCK levels in patients with pancreatic insufficiency. Dig. Dis Sci 1988; 33: 276-81.

10 Canton P. Petronijevic L, Worning H. Plasma cholecystokinin concentrations in patients with advanced chronic pancreatitis. Pancreas 1986; 1: 488-93.

11 Jansen JBMJ, Hopman WPM, Lamers CBHW. Plasma cholecystokinin concentrations in patients with pancreatic insufficiency measured by sequence-specific radioimmunoassays. Dig Dis Sci 1984; 29: 1109-17.

12 Byrnes DJ, Borody T, Henderson L. Plasma cholecystokinin Regul Pept 1980; [Suppl 1]: S15.

13 Jansen JBMJ, Jebbing MCW, Lamers CBHW. Effect of pancreatic enzymes on postprandial plasma cholecystokinin secretion. Digestion 1987; 38: 26-7.

14 Funakoshi A, Nakano I, Shinozaki H, Ibayashi H, Tateishi K. Hamaoka T. Low plasma cholecystokinin response after ingestion of a test meal in patients with chronic pancreatitis. Am J Gastroenterol 1985; 80: 93740.

15 Meyer JH, Jones RS. Canine pancreatic responses to intestinally perfused fat and products of fat digestion. Am J Physiol 1974; 226: 1178-87.

16 Malagelada JR, Dimagno EP. Summerskill WHJ, Go VLW. Regulation of pancreatic and gallbladder functions by intra-luminal fatty acids and bile acids in man. J Clin Invest 1976; 58: 493-9.

17 Krishnamurthy GT, Bobba VR, Kingston E. Radionuclide ejection fraction: a technique for quantitative analysis of motor function of the human gallbladder. Gastroenterology 1981; 80: 482-90.

18 Jansen JBMJ, Lamers CBHW. Radioimmunassay of cholecystokinin in human tissue and plasma. Clin Chim Acta 1983; 131: 305-16.

19 Jansen JBMJ, Lamers CBHW. Molecular forms of cholecystokinin in plasma from normal and gastrectomized human subjects following a fat meal. Peptides 1987; 8: 801-5.

20 Hopman WPM, Jansen JBMJ, Rosenbusch G, Lamers CBHW. Effect of equimolar amounts of long-chain triglycerides and medium-chain triglycerides on plasma cholecystokinin and gallbladder contraction. Am J Clin Nutr 1984; 39: 256-9.

21 Singer MV, Solomon TE, Wood J, Grossman MI. Latency of pancreatic enzyme response to intraduodenal stimulants. Am J Physiol 1980; 238: 623-9.

22 Bradshaw MJ, Mauad EC, Richardson RB, et al. Impaired gallbladder response to intravenous caerulein in patients with chronic pancreatitis. Digestion 1983; 28: $15-6$. 